\title{
Vaccines for SARS-CoV-2: Lessons from Other Coronavirus Strains
}

Eriko Padron-Regalado

\section{ABSTRACT}

The emergence of the strain of coronavirus SARS-CoV-2 (severe acute respiratory syndrome coronavirus 2) and its impact on global health have made imperative the development of effective and safe vaccines for this lethal strain. SARS-CoV-2 now adds to the list of coronavirus diseases that have threatened global health, along with the SARS (severe acute respiratory syndrome) and MERS (Middle East respiratory syndrome) coronaviruses that emerged in 2002/2003 and 2012, respectively. As of April 2020, no vaccine is commercially available for these coronavirus strains. Nevertheless, the knowledge obtained from the vaccine development efforts for MERS and SARS can be of high value for COVID-19 (coronavirus disease 2019). Here, we review the past and ongoing vaccine development efforts for clinically relevant coronavirus strains with the intention that this information helps in the development of effective and safe vaccines for COVID-19. In addition, information from naturally exposed individuals and animal models to coronavirus strains is described for the same purpose of

Digital Features To view digital features for this article go to https://doi.org/10.6084/m9.figshare.12123771.

E. Padron-Regalado ( $₫)$

Nuffield Department of Medicine, University of Oxford, Oxford, Oxfordshire, UK

e-mail: eriko.padronregalado@gmail.com helping into the development of effective vaccines against COVID-19.

Keywords: Coronavirus; COVID-19; MERS; SARS; Vaccine

\section{Key Summary Points}

Current and past vaccine development efforts for SARS and MERS coronaviruses.

Current vaccine development for COVID19 (SARS-CoV-2).

Correlates of protection and other immunologic features surrounding coronavirus strains.

Implications for developing effective vaccines for clinically relevant coronaviruses.

\section{INTRODUCTION}

Coronaviruses are a group of viruses that belong to the family Coronaviridae $[1,2]$. These are enveloped viruses with a positive-sense singlestranded RNA genome and a nucleocapsid of helical symmetry. Their genome size is 
relatively large for RNA viruses, between 27 and $34 \mathrm{kB}$ [3]. Coronaviruses infect mammals and birds causing varied symptoms such as respiratory tract disease and diarrhea. In humans, coronavirus infections have been shown to be potentially lethal. This is the case of severe acute respiratory syndrome (SARS) and the Middle East respiratory syndrome (MERS) coronaviruses.

In 2002-2003, the world experienced what would become the first of a series of lethal coronavirus infections. The disease denominated severe acute respiratory syndrome (SARS) would be characterized by high fever, eventually developing into shortness of breath and pneumonia [4]. Originating in southern China, the disease later would cause 8096 cases, resulting in 774 deaths in 26 countries [5]. Despite efforts from the scientific community, no vaccine became commercially available and SARS cases ceased to be reported from 2004 [4].

In September 2012, the world experienced the emergence of the Middle East respiratory syndrome (MERS) coronavirus. Originated in Saudi Arabia, the infectious disease is characterized by mild respiratory symptoms, but these could develop into acute respiratory distress syndrome and death [6]. The disease has affected 27 countries, resulting in 2494 cases and 858 deaths [7]. MERS cases are still being reported but no major outbreak has been declared since 2015 [8]. As in the case of SARS, no commercial vaccine is available for MERS.

Reasons for the lack of commercial and effective vaccines for SARS and MERS are varied. In the case of MERS, it is likely that the vaccine development was delayed because of the scarcity of suitable and cost-effective small animal models during pre-clinical experimentation. In addition, it is probable that a vaccine has not been delivered because of the low interest in investing in a vaccine for a disease that has produced relatively low and geographically centralized cases (compared with other more global and persistent infectious diseases such as influenza, HIV and tuberculosis). This last factor might have also contributed to the lack of a vaccine for SARS, in the sense that it was considered pointless to continue investing in a vaccine for a disease whose cases ceased to be reported in 2004.

Coronavirus disease 2019 (COVID-19) is a current pandemic caused by the severe acute respiratory syndrome coronavirus 2 (SARS-CoV$2)$. The first cases were reported from Wuhan, China, in December 2019 [9, 10]. According to the World Health Organization (WHO), the disease has been reported in 213 countries and territories as of April 11, 2020, with evidence of ongoing local transmission [11]. According to the same organization, there are $1,669,595$ confirmed cases and 106,138 deaths associated with the disease. Symptoms of COVID-19 are mild and include fever, cough and shortness of breath. Nevertheless, the disease might progress into severe pneumonia and multi-organ failure predominantly in elders and people with other underlying diseases $[9,12]$.

Although no vaccines are commercially available for SARS and MERS, past and current vaccine development efforts against these diseases might be of high value for the development of an effective vaccine for COVID-19. The present review aims to describe these efforts. Furthermore, we describe the possible implications of creating an effective vaccine against COVID-19 taking as a starting point results obtained from other clinically relevant coronavirus strains. We focused our review on active immunization approaches as this offers the possibility of a longer-term prevention for these diseases. This article is based on previously conducted studies and does not contain any studies with human participants or animals performed by any of the authors.

\section{VACCINES FOR SEVERE ACUTE RESPIRATORY SYNDROME (SARS) CORONAVIRUS}

After the SARS epidemic in 2002-2003, several laboratories around the world started to conduct vaccine development studies for preventing the disease. The majority of the subunit vaccines (vaccines based on a specific protein constituting the virus [13]) targeted the spike (S) glycoprotein of the virus. SARS-CoV uses this glycoprotein to bind and enter the host cells 
[14]. Therefore, a vaccine that induces strong immune responses against this protein will have a significant effect on the deterrence of virus entry to the host cells during natural infection.

Vaccines based on a live-attenuated or inactivated virus, recombinant viral vectors, DNA, virus-like particles (VLPs) and soluble proteins were studied, mainly in pre-clinical studies. Live-attenuated and inactivated viruses are based on the use of the whole SARS-CoV as a vaccine. The virus has been rendered nonreplicating, and infectivity has been greatly reduced by means of deleting components of the virus genome or by using physical or chemical methods [15]. In the case of recombinant viral vectors, viruses different from the SARS-CoV that are capable of host cell infection have been genetically engineered to express components of the SARS-CoV [16]. VLPs are non-infectious multiprotein structures formed from viral proteins that self-assemble into viruslike structures [17]. Table 1 summarizes these vaccines and the outcome from pre-clinical and clinical studies.

To our knowledge, only vaccines based on an inactivated SARS virus, DNA and soluble proteins based on the SARS S glycoprotein reached a clinical stage (phase I) [18-20]. It is desired in the field of vaccine development to know for certain if a vaccine can provide protection from virus infection and clinical signs. This is usually performed by exposing (challenging) vaccinated individuals and animal models to the virus in question. Due to the virulence of the SARS coronavirus, challenge studies in humans were not performed; therefore, the protective efficacy of the vaccines was not assessed.

\section{VACCINES FOR THE MIDDLE EAST RESPIRATORY SYNDROME (MERS) CORONAVIRUS}

Several vaccines have been developed for MERS coronavirus since its emergence in 2012. As in the case of the SARS vaccines, most of the subunit vaccines for MERS are based on the S glycoprotein. Vaccines based on inactivated and live attenuated viruses, recombinant viral vectors, nanoparticles (conglomerate of antigenic proteins of "nano" size [57]), DNA and soluble proteins have been developed and tested predominantly in animal models (Fig. 1; Table 2). To our knowledge, only a DNA-based vaccine has already been tested in clinical trials (phase I) [58] with other vaccines such as MVA (modified vaccinia virus Ankara) and adenoviruses being currently under study at that clinical stage $[59,60]$.

\section{VACCINE FOR CORONAVIRUS DISEASE 2019 (COVID-19)}

Vaccines for COVID-19 are in pre-clinical development, and no clinical stage has been completed because of the recent emergence of the disease (as of April 13, 2020). Several entities from the globe have declared their intentions to develop a vaccine for COVID-19. According to the WHO, 41 candidate vaccines are being developed for COVID-19 as of March 13, 2020 [93]. Information about the nature of these vaccines under development is publicly scarce. Table 3 summarizes these current development efforts with information supplemented from other public sources. As of March 13, 2020, only one vaccine has started clinical trials (phase I). This vaccine is being developed by Moderna (USA), and it uses an mRNA-based vaccine expressing the SARS-CoV-2 S glycoprotein [94].

\section{TOWARD PROTECTIVE VACCINES FOR CLINICALLY RELEVANT CORONAVIRUS STRAINS}

The vaccine development efforts for SARS and MERS coronavirus should help in the development of effective vaccines for COVID-19. This section aims to describe important information obtained from these experiments and to explore areas of opportunity for the development of effective vaccines for clinically relevant coronaviruses.

\section{Animal Models}

The development of effective vaccines for SARS and MERS was slowed down by the lack of 


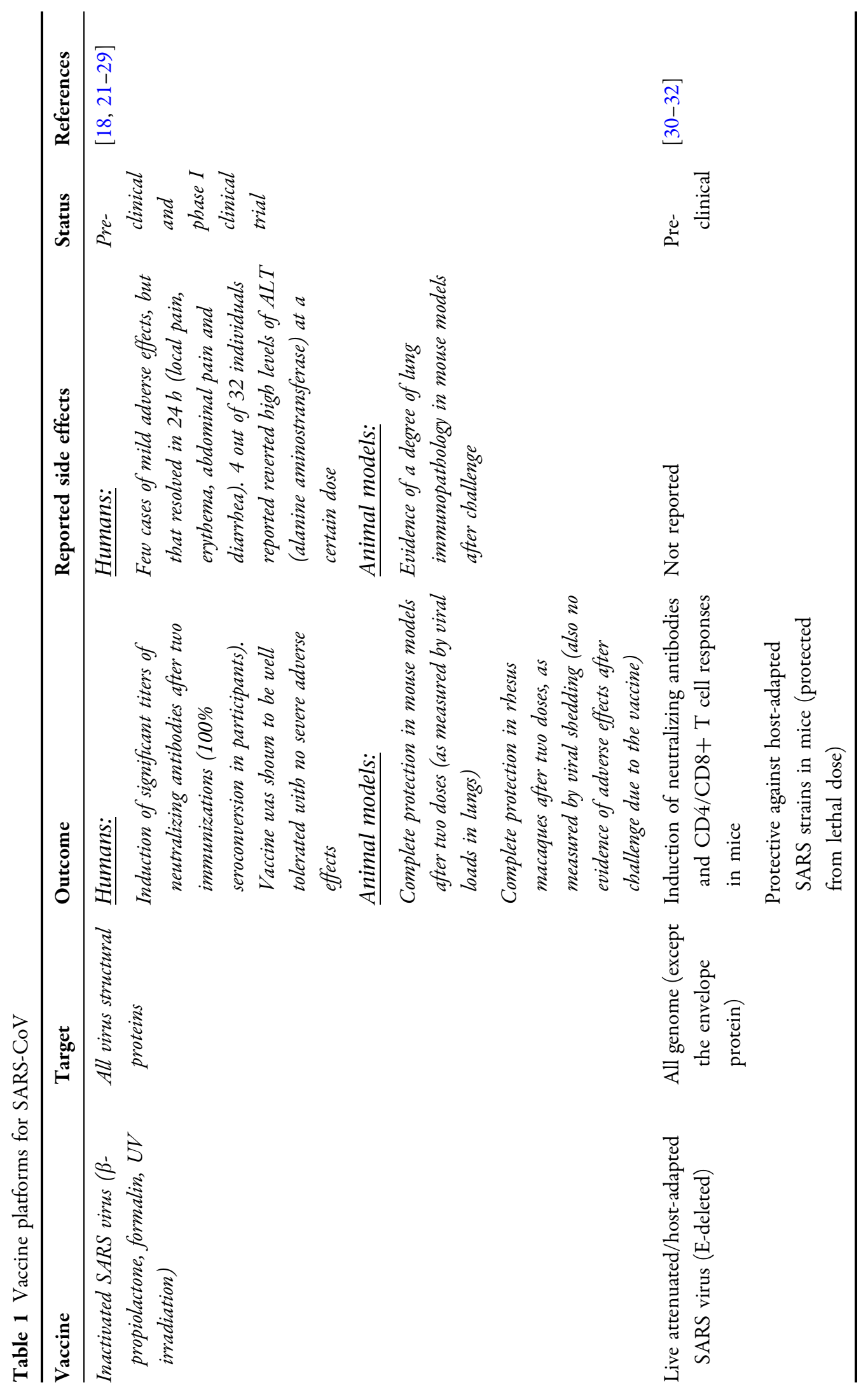




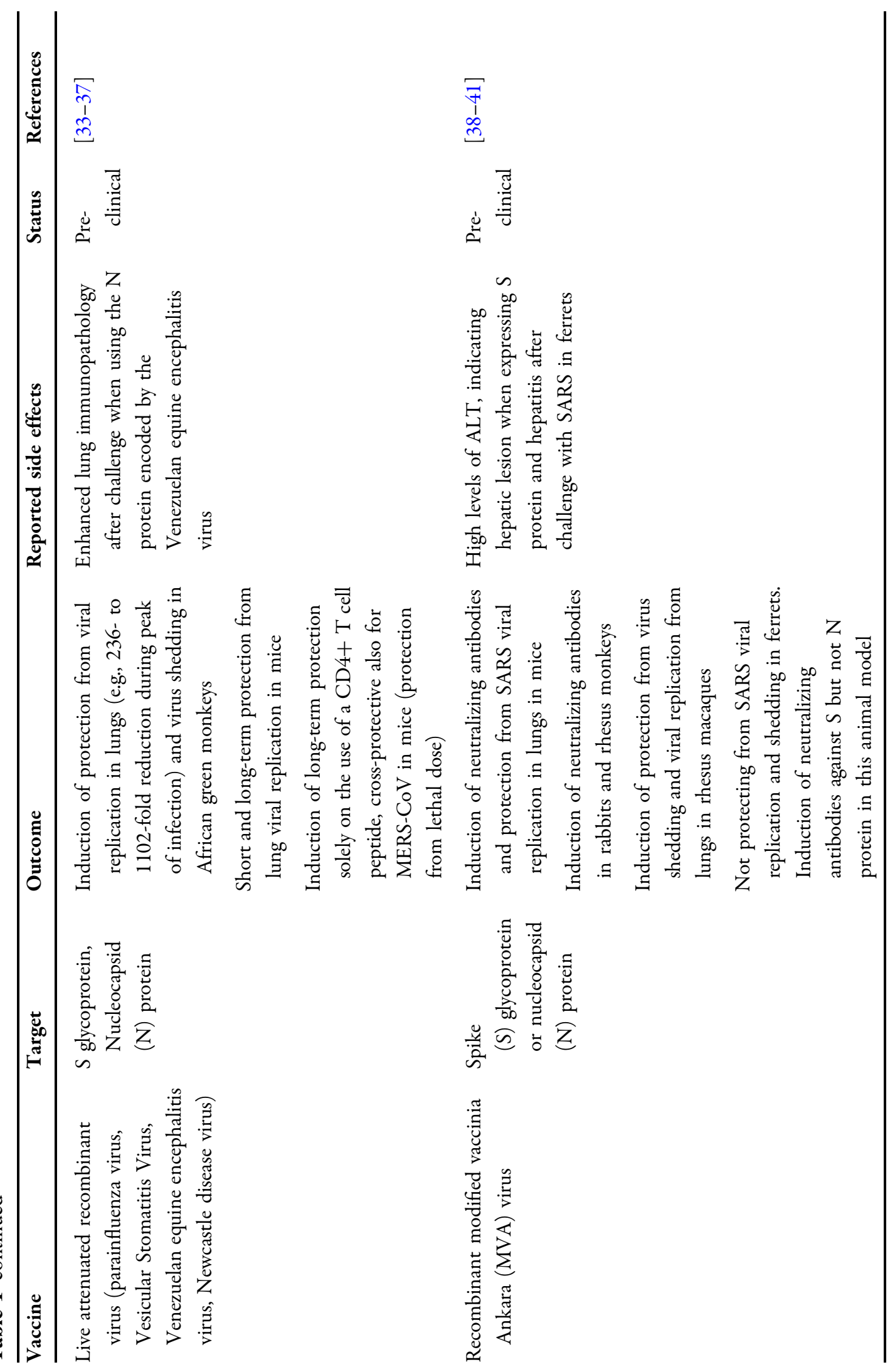




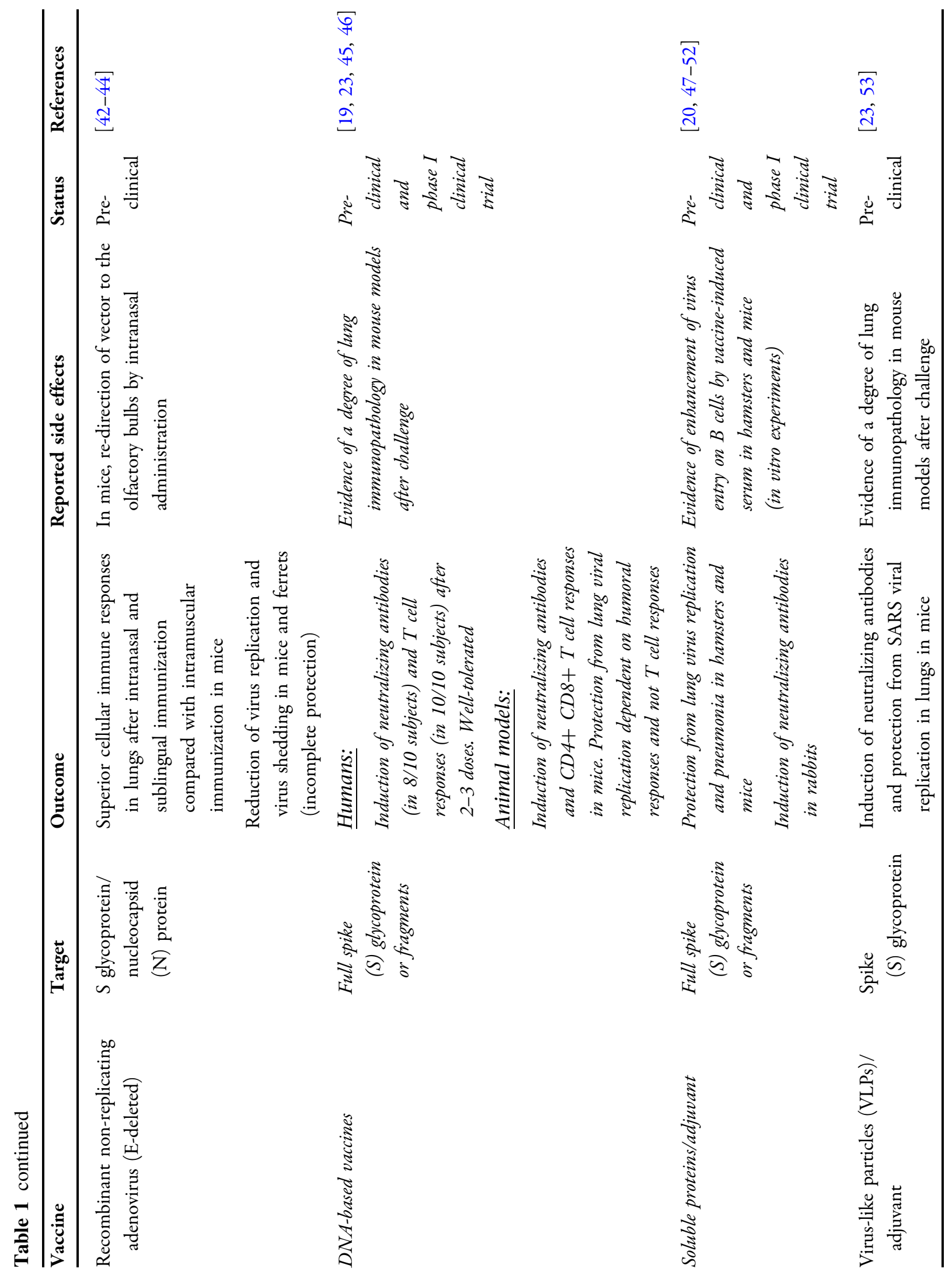




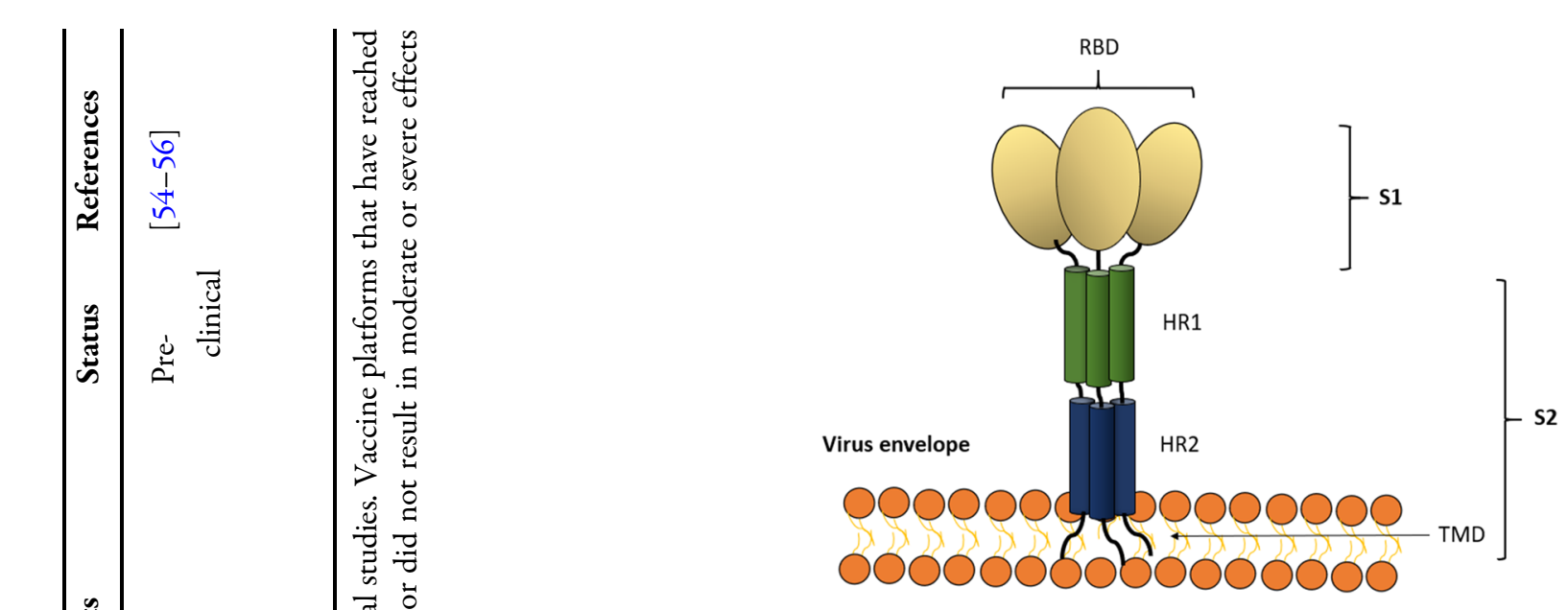

Fig. 1 Scheme of the structure of the spike $(S)$ glycoprotein of the MERS coronavirus used in vaccine development (modified from [61]). The MERS coronavirus $S$ glycoprotein is used predominantly in vaccine development for coronaviruses. The $S$ glycoprotein induces high titers of neutralizing antibodies, and the protein has been frequently exploited in subunit vaccination. In nature, the $S$ glycoprotein binds to the host cell receptor DPP4 (dipeptidyl peptidase 4) through the receptor-binding domain (RBD) of the $S$ glycoprotein [62]. The $S$ glycoprotein can be divided into two subunits, $S 1$ and S2. The subunit S1 contains the RBD. The subunit S2 contains heptad repeat regions (HR1 and HR2) that the virus uses for membrane fusion and entry to the host cell. The $S$ glycoprotein is a class I fusion protein, and it exists as a trimer, as depicted. DPP4 dipeptidyl peptidase 4, $S 1$ $S 1$ subunit of $S, S 2 S 2$ subunit of $S, R B D$ receptor binding domain. $T M D$ transmembrane domain

suitable animal models for testing these vaccines. Even though animal models develop immunologic responses to SARS and MERS coronaviruses, these animals show limited viral replication and clinical manifestations of disease (fever, cough, runny nose, shortness of breath, viremia, pneumonia), usually not leading to death [95]. This has produced certain limitations for evaluating protection conferred by the vaccines.

Several studies addressed the issue of the lack of a suitable animal model by using transgenic animal models that rendered these animals more permissive to coronavirus infection. By these means, the animal models allowed systemic virus replication and the analysis of more severe and clinically relevant symptoms of the 
Table 2 Vaccine platforms for MERS-CoV

\begin{tabular}{|c|c|c|c|c|c|}
\hline Vaccine & Target & Outcome & $\begin{array}{l}\text { Reported side } \\
\text { effects }\end{array}$ & Status & References \\
\hline $\begin{array}{l}\text { Live attenuated } \\
\text { MERS-CoV (E } \\
\text { envelope- } \\
\text { deleted) }\end{array}$ & $\begin{array}{l}\text { All virus } \\
\text { genome } \\
\text { components } \\
\text { (except E) }\end{array}$ & Not yet tested in vivo & Not yet tested in vivo & In vitro & {$[63]$} \\
\hline $\begin{array}{l}\text { Chemically or } \\
\text { physically- } \\
\text { Inactivated } \\
\text { virus (MERS- } \\
\text { CoV, rabies } \\
\text { virus) }\end{array}$ & $\begin{array}{l}S \text { glycoprotein } \\
\text { and } S 1 \\
\text { subunit }\end{array}$ & $\begin{array}{l}\text { Induction of high titers of } \\
\text { neutralizing antibodies, } \\
\text { protection from lung } \\
\text { viral loads and lung } \\
\text { pathologic damage in } \\
\text { humanized mice }\end{array}$ & $\begin{array}{l}\text { Enhanced lung } \\
\text { eosinophil } \\
\text { infiltrations after } \\
\text { challenge }\end{array}$ & Pre-clinical & {$[64-66]$} \\
\hline $\begin{array}{l}\text { Replication- } \\
\text { deficient viral- } \\
\text { vectored vaccines } \\
\text { (poxvirus, } \\
\text { adenovirus, } \\
\text { measles, rabies) }\end{array}$ & $\begin{array}{l}\text { S glycoprotein or } \\
\text { S1 subdomain } \\
\text { (containing } \\
\text { the receptor- } \\
\text { binding } \\
\text { protein) }\end{array}$ & $\begin{array}{l}\text { Induction of both } \\
\text { neutralizing antibody } \\
\text { responses and long-term } T \\
\text { cell responses in animal } \\
\text { models } \\
\text { Protection from lung viral } \\
\text { replication and MERS- } \\
\text { CoV lethal dose in } \\
\text { bumanized mice } \\
\text { Protection from viral } \\
\text { shedding in camels }\end{array}$ & $\begin{array}{l}\text { Use of S1 subunit in } \\
\text { an adenovirus- } \\
\text { based vaccine } \\
\text { induced lung } \\
\text { pathology in mice } \\
\text { after challenge }\end{array}$ & Phase I & {$[59,67-76]$} \\
\hline $\begin{array}{l}\text { Soluble protein } \\
\text { vaccines/ } \\
\text { adjuvant }\end{array}$ & $\begin{array}{l}S \text { glycoprotein } \\
\text { and } \\
\text { fragments }\end{array}$ & $\begin{array}{l}\text { Induction of neutralizing } \\
\text { antibodies and } \mathrm{T} \text { cell } \\
\text { responses in animal } \\
\text { models } \\
\text { Protection from lung viral } \\
\text { loads and from lethal dose } \\
\text { in humanized mice } \\
\text { Protection from virus } \\
\text { shedding in camels and } \\
\text { alpacas } \\
\text { Partial protection in rhesus } \\
\text { macaques (vaccine did not } \\
\text { completely prevent } \\
\text { pneumonia) }\end{array}$ & Not reported & Pre-clinical & {$[77-87]$} \\
\hline
\end{tabular}


Table 2 continued

\begin{tabular}{|c|c|c|c|c|c|}
\hline Vaccine & Target & Outcome & $\begin{array}{l}\text { Reported side } \\
\text { effects }\end{array}$ & Status & References \\
\hline Nanoparticles & S glycoprotein & $\begin{array}{l}\text { Induction of neutralizing } \\
\text { antibody titers and } \\
\text { reduction of viral } \\
\text { replication in lungs of } \\
\text { mice }\end{array}$ & Not reported & Pre-clinical & {$[88,89]$} \\
\hline $\begin{array}{l}\text { DNA-based } \\
\text { vaccines }\end{array}$ & $\begin{array}{l}S \text { glycoprotein } \\
\text { and subunits }\end{array}$ & $\begin{array}{l}\text { Humans: } \\
\text { Induction of neutralizing } \\
\text { antibodies (48\% of } \\
\text { participants) and T cell } \\
\text { responses ( } 76 \% \text { of } \\
\text { participants) after three } \\
\text { doses (phase I clinical trial) } \\
\text { Animal models: } \\
\text { Partially protective in non- } \\
\text { human primates } \\
\text { (observance of lung viral } \\
\text { loads and pneumonia) } \\
\text { Induction of neutralizing } \\
\text { antibodies and T cell } \\
\text { responses in mice. Also, } \\
\text { protective from lung viral } \\
\text { loads }\end{array}$ & $\begin{array}{l}\text { Moderate and mild } \\
\text { symptoms in phase I } \\
\text { clinical trial }\end{array}$ & $\begin{array}{l}\text { Phase I/IIa } \\
\text { (South } \\
\text { Korea) } \\
\text { and phase } \\
\text { II } \\
\text { (Middle } \\
\text { East) }\end{array}$ & {$[58,76,90-92]$} \\
\hline $\begin{array}{l}\text { Combination } \\
\text { vaccines } \\
\text { (protein and } \\
\text { DNA) }\end{array}$ & $\begin{array}{l}S \text { glycoprotein } \\
\text { and subunits }\end{array}$ & $\begin{array}{l}\text { Induction of long-lived } \\
\text { neutralizing antibodies } \\
\text { and protection from } \\
\text { pneumonia in non- } \\
\text { human primates }\end{array}$ & Not reported & Pre-clinical & {$[78]$} \\
\hline
\end{tabular}

The table summarizes the vaccine development efforts (past and current) for MERS-CoV and the results obtained from the pre-clinical and clinical studies. Vaccine platforms that have reached clinical trials are highlighted in italics. "Not reported side effects" means that side effects studies were not performed or did not result in moderate or severe effects

SARS and MERS diseases [31, 43, 68, 69, 76, 96]. For example, transgenic mice were created to express the human cell receptor of SARS-CoV (human angiotensin-converting enzyme 2). This allowed the enhancement of infection sensitivity and the evaluation of protection from lethal doses of the virus [31]. Other approaches involved the use of mouse-adapted coronavirus strains that could replicate and induce health conditions that resemble human infection (e.g., severe pneumonia, viremia leading to death) [30-32, 47]. Transgenic mouse models for SARS and MERS are now commercially available.

Non-human primates have also been used for testing protection in coronavirus 
Table 3 Vaccines under development for COVID-19 according to the WHO as of March 13, 2020 (adapted from [93])

\begin{tabular}{|c|c|c|}
\hline Vaccine & Target & Producing entity (country) \\
\hline Inactivated virus/alum & $\begin{array}{l}\text { All structural } \\
\text { proteins of the } \\
\text { virus }\end{array}$ & Sinovac Biotech (China) \\
\hline Virus-like particle (VLP) & Unknown & $\begin{array}{l}\text { Medicago (Canada), ExpreS2ion Biotechnologies ApS } \\
\text { (Denmark), Griffith University (Australia) }\end{array}$ \\
\hline Protein nanoparticles/Matrix-M & S glycoprotein & Novavax/Emergent Biosolutions (USA) \\
\hline $\begin{array}{l}\text { Non-replicating viral vector } \\
\text { (adenovirus, chimeric } \\
\text { chimpanzeeadenovirus, } \mathrm{MVA}^{*} \text { ) } \\
\text { *Vaccine expressing a VLP }\end{array}$ & $\begin{array}{l}\text { S glycoprotein/ } \\
\text { unknown }\end{array}$ & $\begin{array}{l}\text { Altimmune (USA), University of Oxford (UK), CanSino } \\
\text { Biologics/Beijing Institute of Biotechnology (China), } \\
\text { Vaxart (USA), Greffex (USA), Janssen Pharmaceutical } \\
\text { (Belgium), GeoVax/BravoVax (USA/China) }\end{array}$ \\
\hline $\begin{array}{l}\text { RNA-based vaccine, RNA vaccine } \\
\text { encoding VLP }\end{array}$ & $\begin{array}{l}\text { S glycoprotein/ } \\
\text { unknown }\end{array}$ & $\begin{array}{l}\text { Moderna/NIAID (USA), CureVac (Germany), Imperial } \\
\text { College London (UK), Arcturus Therapeutics/Duke- } \\
\text { NUS Medical School (USA), Fudan University/Shanghai } \\
\text { JiaoTong University/RNACure Biopharma (China), } \\
\text { China CDC/Tongii University/Stermina (China), } \\
\text { BioNTech/Fosum Pharma/Pfizer (Germany/China/ } \\
\text { USA) }\end{array}$ \\
\hline DNA-based vaccine & $\begin{array}{l}\text { S glycoprotein/ } \\
\text { unknown }\end{array}$ & $\begin{array}{l}\text { Inovio Pharmaceuticals (USA), Zydus Cadila (India), Takis } \\
\text { Biotech/Applied DNA Sciences/Evvivax (USA/Italy), } \\
\text { Sanofi Pasteur/BARDA (France/USA) }\end{array}$ \\
\hline Protein subunit & $\begin{array}{l}\text { S glycoprotein and } \\
\text { peptides/ } \\
\text { unknown }\end{array}$ & $\begin{array}{l}\text { WRAIR/USAMRIID (USA), Clover Biopharmaceuticals } \\
\text { Inc./GSK (China/UK), Vaxil Bio (Israel), Generex/ } \\
\text { EpiVax, EpiVax/University of Georgia (Canada/USA), } \\
\text { Sanofi Pasteur (France), University of Queensland } \\
\text { (Australia), Baylor College of Medicine/New York Blood } \\
\text { Center (USA), Fudan University (China), iBio Pharma/ } \\
\text { CC-Pharming (USA/China), AJ Vaccines (Denmark), } \\
\text { Heat Biologics/University of Miami (USA) }\end{array}$ \\
\hline Live attenuated virus & $\begin{array}{l}\text { All proteins of the } \\
\text { virus }\end{array}$ & Codagenix/Serum Institute of India (USA/India) \\
\hline $\begin{array}{l}\text { Replicating viral vector (measles, } \\
\text { horsepox) }\end{array}$ & Unknown & $\begin{array}{l}\text { Zydus Cadila (India), Pasteur Institute/Themis/University } \\
\text { of Pittsburg (France/USA), Tonix Pharma/Southern } \\
\text { Research (USA) }\end{array}$ \\
\hline Unknown & Unknown & $\begin{array}{l}\text { University of Pittsburgh (USA), University of Saskatchewan } \\
\text { (Canada), MIGAL Galilee Research Institute (Israel), } \\
\text { Peter Doherty Institute (Australia), Academy of Military } \\
\text { Medical Sciences (China), Tulane University (USA), } \\
\text { Flinders University/Vaxine Pty Ltd (Australia) }\end{array}$ \\
\hline
\end{tabular}


vaccination. In the case of MERS, rhesus macaques allow virus replication but they do not seem to develop severe clinical symptoms (increased respiratory rate, fever, cough) [97, 98]. Common marmosets have been shown to display severe symptoms of disease, leading to death $[99,100]$, but information about their use in active vaccination experiments is scarce. In the case of SARS, the virus shows varied lung pathologies and limited clinical symptoms in cynomolgus macaques and African green monkeys [101, 102]. This symptomatology, although limited, has allowed analyzing the conferring of protection from vaccine candidates.

\section{Correlates of Protection}

It is generally accepted that neutralizing antibodies against the SARS and MERS S glycoproteins play a predominant role in the protection against these coronaviruses [103, 104]. Neutralizing antibodies are antibodies that bind and neutralize virus infection of host cells [105]. Vaccinated animals and passive immunization approaches focusing on the MERS and SARS S glycoproteins induced high titers of neutralizing antibodies that correlated with protection $[39,43,45,49,53,106,107]$. Nevertheless, it is still in doubt whether adaptive $\mathrm{T}$ cell responses (another arm of the immune system) can also play a role in conferring protection, with few studies addressing this issue. As an example, a group of researchers demonstrated that specific $\mathrm{CD} 4+$ and $\mathrm{CD} 8+\mathrm{T}$ cell peptides against SARS$\mathrm{CoV}$ could be exploited to provide protection in mice $[37,108,109]$. Another study pointed out that the protection against SARS-CoV in mice induced by a DNA vaccine was due only to antibody responses (depletion of CD4/CD8+ T cells and adoptive $\mathrm{T}$ cell transfer did not have an effect on protection) [45]. In MERS, vaccination efficacy in non-human primates has been correlated to the induction of $\mathrm{CD} 8+\mathrm{T}$ cell responses (in addition to neutralizing antibodies) when using DNA-based vaccines [78]. It is then likely that protection induced by vaccination might be dependent on different factors such as the selected vaccination platform, antigens, animal models and routes of vaccination.

Few animal experiments have addressed the question of whether a certain vaccination regimen could induce long-term protection. In the case of SARS, viral vectors and protein-based vaccines employing the $S$ glycoprotein have shown a certain level of protection from infection (in at least $75 \%$ of mice) after 4-12 months of vaccination $[34,35,49]$. In the case of MERS, protein-based vaccines and a combination of DNA and protein-based vaccines have been shown to induce a certain level of long-term protection in mice and macaques $[78,79]$. In general, these studies focus on the induction of persistent neutralizing antibodies during vaccination, while the contribution of T-cell responses is not frequently addressed.

\section{Natural Infection of Coronavirus Strains}

Exposure to SARS and MERS coronaviruses can also shed light on the possible mechanisms of protection. In humans, rapid and strong neutralizing antibody responses are highly correlated to the severity of the disease and the recovery of the patient. Nevertheless, $\mathrm{T}$ cell responses might also play a role in the elimination of the virus during infection, therefore also likely supporting the recovery of the patient [110-114]. From these studies, the induction of both arms of the immune response is likely necessary for the effective elimination of the virus and recovery from the disease.

In vaccine development, it is ideal that a vaccine provides long-term protection. Whether long-term protection can be achieved by means of vaccination or exposure to coronaviruses is under debate, and more information is needed in this regard. For SARS-CoV, memory $T$ cells, but not B cells, could be detected 6 years after infection in human survivors [115]. Nevertheless, a certain level of neutralizing antibodies can be tracked until 24 months after infection, opening the possibility of a certain level of protection during this time frame due to this humoral response [116]. In the case of MERS, little is known about the generation of memory B cells, but neutralizing antibodies are 
known to persist for 34 months [117]. In the case of memory T cells, CD4+ and CD8+ T cell responses have been detected 24 months after infection [114].

Other human coronaviruses can offer some clues about the induction of long-term protection. In the cases of human coronaviruses HCoV-229E and HCoV-OC43, these respiratory viruses do not cause long-lived protection as challenge experiments suggest, even when antibody responses are detected in the long run $[118,119]$.

\section{Safety}

Studies about the safety of vaccines against SARS and MERS are relatively scarce. There is a concern about the induction of antigen-dependent enhancement (ADE) and other adverse effects derived from vaccination or natural reexposure. ADE is a phenomenon that occurs when non-neutralizing antibodies against proteins of a virus enhance virus entry to host cells, also enhancing virus infectivity [120]. ADE has been already observed in cats vaccinated against a species-specific coronavirus (feline infectious peritonitis coronavirus) [121]. In the case of SARS, antibody-dependent enhancement and other adverse effects induced by vaccination in animal models have raised some concern.

It has been found that certain vaccine platforms expressing the SARS S glycoprotein or using a whole inactivated virus induced lung immunopathology and hepatitis after challenge in some animal models [23, 29, 38, 40]. Furthermore, MERS coronavirus vaccination has been shown to induce pulmonary infiltration after challenge in mice when using an inactivated MERS-CoV vaccine [66]. Of note, some SARS-CoV-infected animal models are not protected from MERS-CoV (and vice versa), and they might develop adverse effects after secondary infection $[96,122]$. Other studies concerning passive antibody transfer in mice and non-human primate experimentation have not found evidence of ADE or pathologic effects $[22,26,33,39,55,123,124]$.

The induction of ADE using the S glycoprotein has been tackled by using truncated versions of the same protein. It is believed that the use of the receptor-binding domain (RBD) or the S1 subunit of the S glycoprotein can lead to the induction of neutralizing antibodies while avoiding ADE. The idea is to focus the induction of antibodies to relevant $S$ regions for efficient virus neutralization and, by doing so, to avoid the induction of potential non-neutralizing antibodies targeting other regions of the $S$ protein. Even though there seems to be little direct evidence proving this idea, vaccines based on these regions have already been tested, allowing the induction of high titers of neutralizing antibodies and a certain level of protection in small animals and non-human primates [49, 50, 56, 78].

The use of adjuvants has also been considered for avoiding the potential undesired effects of coronavirus vaccination. Adjuvants are substances that potentiate and modify the immunogenicity and protection efficacy of the vaccines [125]. A group of researchers found that by using a chemical adjuvant (a delta inulin-based polysaccharide), lung immunopathology previously observed in mice after SARS challenge experiments were no longer observed [126]. It was hypothesized that the adjuvant helped to avoid an exacerbated Th2-polarized response after challenge causative of the adverse effects. This is a case where an adjuvant not only enhanced vaccine-induced protection but also helped to minimize adverse effects due to coronavirus vaccination.

\section{Areas of Opportunity in the Development of Vaccines for Coronaviruses}

Experiments directly comparing vaccine platforms and approaches for coronaviruses are scarce. A group of scientists discovered that, at a certain dose, DNA and MVA-based vaccines encoding the $S$ glycoprotein of MERS develop similar levels of neutralizing antibodies [106]. In another study, vaccines based on heterologous prime-boost vaccination (DNA followed by protein-based vaccination) induced higher neutralizing antibody titers and protection than homologous prime-boost vaccination approaches; this is in mice and non-human primates 
[127]. Nevertheless, a different number of immunizations were performed using different subunits of the $\mathrm{S}$ glycoprotein. Therefore, it is difficult to determine whether a given vaccine platform would be more immunogenic and protective than others solely on terms of the vaccine platform used. This information could potentially lead to the selection of ideal vaccine platforms for coronaviruses.

Although inactivated viruses, DNA and viral vector-based vaccines have been tested for SARS and MERS coronavirus in clinical trials, other vaccine platforms are yet to be tested. An mRNA-based vaccine, a relatively recent technology, is being tested for COVID-19 in phase I clinical trials [128] with other companies starting clinical trials soon as of April 11 of the year of this publication [129]. Due to the relatively new emergence of such vaccine platforms, their performance with coronavirus diseases is still to be known.

Different routes of vaccination could also help in the development of effective vaccines for coronaviruses. Considering that SARS and MERS-CoV are respiratory viruses, inducing memory responses in the respiratory tract would be advantageous. A group of researchers has found that inducing cellular and antibody responses in the respiratory tract by means of intranasal vaccination might induce higher protection levels in mice $[37,43]$.

Even though targeting the spike glycoprotein in vaccine development could be ideal for inducing neutralizing antibodies, the selection of other antigens might also offer some advantages. For example, the nucleocapsid (N) protein is more conserved between SARS and MERS coronavirus strains [130]. In addition, the $\mathrm{N}$ protein induces long-lived memory $\mathrm{T}$-cells in humans [131]. Peptides derived from this protein have been shown to induce cross-protection against SARS and MERS in mouse experiments [37]. Therefore, the $\mathrm{N}$ protein could serve as a potentially viable alternative to provide cross-protective and long-term T-cell immunity against coronaviruses.

\section{CONCLUSIONS}

The vaccine development efforts for coronavirus strains such as SARS and MERS can help to direct the vaccine development efforts for COVID-19. The development of highly effective and safe vaccines for COVID-19 should consider aspects such as the possibility of ADE and other adverse effects previously observed with SARS and MERS. Even though these features have only been seen in some animal models and vaccination regimens, the possibility is still there to be considered for COVID-19. In addition, these vaccine development efforts should address the possibility of the short-term immunogenicity derived from neutralizing antibodies, as also previously observed for SARS and MERS-CoV after natural infection.

The possibility of exploiting $\mathrm{T}$ cell responses for coronavirus vaccination should also be considered (along with B cell responses). These responses have been shown to be persistent and protective in animal models. Furthermore, there is evidence of long-term persistence in humans. Strategies such as adjuvantation, tailoring of the $\mathrm{S}$ glycoprotein, different routes of vaccination and the use of unexplored vaccine platforms for enhancing immunogenicity and preventing potential undesired effects should also be considered. It is worth mentioning that employing the $\mathrm{N}$ protein of the coronavirus for vaccination could have several benefits. As previously mentioned, there is the potential of providing long-term cross-protection when employing this antigen. Of note, the evidence of short-term immunogenicity and protection in coronavirus-exposed individuals does not mean that an effective vaccine is not possible. Vaccines for other now eradicated diseases that lack naturally acquired immunity prove this point (e.g., smallpox). The emergence of COVID-19 should also serve for elevating our comprehension and expertise in the abatement of pathogenic microorganisms of global health importance. 


\section{ACKNOWLEDGEMENTS}

We thank Eduardo Gorron from the University of Queensland (Australia) for providing useful comments during the writing of the present article.

Funding. No funding or sponsorship was received for this study or publication of this article.

Authorship. All named authors meet the International Committee of Medical Journal Editors (ICMJE) criteria for authorship for this article, take responsibility for the integrity of the work as a whole, and have given their approval for this version to be published.

Disclosures. Eriko Padron-Regalado declares no conflict of interest.

Compliance with Ethics Guidelines. This article is based on previously conducted studies and does not contain any studies with human participants or animals performed by any of the authors.

Data Availability. Data sharing is not applicable to this article as no datasets were generated or analyzed during the current study.

Open Access. This article is licensed under a Creative Commons Attribution-NonCommercial 4.0 International License, which permits any non-commercial use, sharing, adaptation, distribution and reproduction in any medium or format, as long as you give appropriate credit to the original author(s) and the source, provide a link to the Creative Commons licence, and indicate if changes were made. The images or other third party material in this article are included in the article's Creative Commons licence, unless indicated otherwise in a credit line to the material. If material is not included in the article's Creative Commons licence and your intended use is not permitted by statutory regulation or exceeds the permitted use, you will need to obtain permission directly from the copyright holder.To view a copy of this licence, visit http://creativecommons.org/licenses/bync/4.0/

\section{REFERENCES}

1. de Groot RJ, Baker SC, Baric R, Enjuanes L, Gorbalenya AE, Holmes KV, Perlman S, Poon L, Rottier PJ, Talbot PJ, Woo PC, Ziebuhr J. Family Coronaviridae. In: King AM, Lefkowitz E, Adams MJ, Carstens EB, editors. Ninth Report of the International Committee on Taxonomy of Viruses. Oxford: El., I. U. of M. S. V. D., International Committee on Taxonomy of Viruses; 2011, p. 806-28.

2. ICTV Master Species List 2009—v10, International Committee on Taxonomy of Viruses.

3. Gorbalenya AE, Enjuanes L, Ziebuhr J, Snijder EJ. Nidovirales: evolving the largest RNA virus genome. Virus Res. 2006;117(1):17-37.

4. NHS, SARS (severe acute respiratory syndrome). [Online]. https://www.nhs.uk/conditions/sars/. Accessed 15 Feb 2020.

5. WHO. Summary of probable SARS cases with onset of illness from 1 November 2002 to 31 July 2003. 2003. [Online]. https://www.who.int/csr/sars/ country/table2004_04_21/en/. Accessed 15 Feb 2020.

6. CDC. MERS Clinical Features, Middle East Respiratory Syndrome (MERS). 2019. [Online]. https:// www.cdc.gov/coronavirus/mers/clinical-features. html. Accessed 15 Feb 2020.

7. WHO. Middle East respiratory syndrome coronavirus (MERS-CoV). 2020. [Online]. https://www. who.int/emergencies/mers-cov/en/. Accessed 3 Apr 2020.

8. WHO. Middle East respiratory syndrome coronavirus (MERS-CoV)-Republic of Korea. 2015. [Online]. https://www.who.int/csr/don/25-october2015-mers-korea/en/. Accessed 15 Feb 2020.

9. Hui DS, et al. The continuing 2019-nCoV epidemic threat of novel coronaviruses to global health; the latest 2019 novel coronavirus outbreak in Wuhan, China. Int J Infect Dis. 2020;91:264-6.

10. WHO. WHO Director-General's opening remarks at the media briefing on COVID-19-11 March 2020. 2020. [Online]. https://www.who.int/dg/speeches/detail/ who-director-general-s-opening-remarks-at-the-mediabriefing-on-covid-19-11-march-2020. Accessed 15 Mar 2020. 
11. WHO. Coronavirus disease 2019 (COVID-19): situation report, 74. 2020. [Online]. https://www.who. int/emergencies/diseases/novel-coronavirus-2019/ situation-reports. Accessed 3 Apr 2020.

12. WHO. Q\&A on coronavirus (COVID-19). 2020. [Online]. https://www.who.int/news-room/q-adetail/q-a-coronaviruses. Accessed 3 Apr 2020.

13. Mak TW, Saunders ME. Chapter 14-Vaccination. In: Jett E, editor. B D. B. T.-P. to the I. R. Primer to the immune response. 2nd ed. Boston: Academic Cell; 2014. p. 333-75.

14. Du L, He Y, Zhou Y, Liu S, Zheng B-J, Jiang S. The spike protein of SARS-CoV-a target for vaccine and therapeutic development. Nat Rev Microbiol. 2009;7(3):226-36.

15. Petrovsky N, Aguilar JC. Vaccine adjuvants: current state and future trends. Immunol Cell Biol. 2004;82(5):488-96.

16. Lauer KB, Borrow R, Blanchard TJ. Multivalent and multipathogen viral vector vaccines. Clin Vaccine Immunol. 2017;24(1):e00298-e316.

17. Urakami A, et al. Development of a novel virus-like particle vaccine platform that mimics the immature form of alphavirus. Clin Vaccine Immunol. 2017;24(7):e00090-e117.

18. Lin J-T, et al. Safety and immunogenicity from a phase I trial of inactivated severe acute respiratory syndrome coronavirus vaccine. Antivir Ther. 2007;12(7):1107-13.

19. Martin JE, et al. A SARS DNA vaccine induces neutralizing antibody and cellular immune responses in healthy adults in a Phase I clinical trial. Vaccine. 2008;26(50):6338-433.

20. NIH-ClinicalTrials.gov, Phase I Dose Escalation SARS-CoV Recombinant S Protein, With and Without Adjuvant, Vaccine Study. 2013. [Online]. https:// clinicaltrials.gov/ct2/show/NCT01376765. Accessed 15 Feb 2020 .

21. Orellana C. Phase I SARS vaccine trial in China. Lancet Infect Dis. 2004;4(7):388.

22. Luo F, Liao F-L, Wang H, Tang H-B, Yang Z-Q, Hou W. Evaluation of antibody-dependent enhancement of SARS-CoV infection in rhesus macaques immunized with an inactivated SARS-CoV vaccine. Virol Sin. 2018;33(2):201-4.

23. Tseng C-T, et al. Immunization with SARS coronavirus vaccines leads to pulmonary immunopathology on challenge with the SARS virus. PLoS One. 2012;7(4):e35421.
24. Takasuka N, et al. A subcutaneously injected UVinactivated SARS coronavirus vaccine elicits systemic humoral immunity in mice. Int Immunol. 2004;16(10):1423-30.

25. Tang $\mathrm{L}$, et al. Inactivated SARS-CoV vaccine prepared from whole virus induces a high level of neutralizing antibodies in BALB/c mice. DNA Cell Biol. 2004;23(6):391-4.

26. Stadler $\mathrm{K}$, et al. SARS vaccine protective in mice. Emerg Infect Dis. 2005;11(8):1312-4.

27. Zhou J, et al. Immunogenicity, safety, and protective efficacy of an inactivated SARS-associated coronavirus vaccine in rhesus monkeys. Vaccine. 2005;23(24):3202-9.

28. Qin E, et al. Immunogenicity and protective efficacy in monkeys of purified inactivated Vero-cell SARS vaccine. Vaccine. 2006;24(7):1028-34.

29. Bolles M, et al. A double-inactivated severe acute respiratory syndrome coronavirus vaccine provides incomplete protection in mice and induces increased eosinophilic proinflammatory pulmonary response upon challenge. J Virol. 2011;85(23): 12201-15.

30. Regla-Nava JA, et al. Severe acute respiratory syndrome coronaviruses with mutations in the E protein are attenuated and promising vaccine candidates. J Virol. 2015;89(7):3870-87.

31. Netland J, et al. Immunization with an attenuated severe acute respiratory syndrome coronavirus deleted in E protein protects against lethal respiratory disease. Virology. 2010;399(1):120-8.

32. Fett C, DeDiego ML, Regla-Nava JA, Enjuanes L, Perlman S. Complete protection against severe acute respiratory syndrome coronavirus-mediated lethal respiratory disease in aged mice by immunization with a mouse-adapted virus lacking $\mathrm{E}$ protein. J Virol. 2013;87(12):6551-9.

33. Bukreyev A, et al. Mucosal immunisation of African green monkeys (Cercopithecus aethiops) with an attenuated parainfluenza virus expressing the SARS coronavirus spike protein for the prevention of SARS. Lancet (London, England). 2004;363(9427): 2122-7.

34. Kapadia SU, Rose JK, Lamirande E, Vogel L, Subbarao K, Roberts A. Long-term protection from SARS coronavirus infection conferred by a single immunization with an attenuated VSV-based vaccine. Virology. 2005;340(2):174-82.

35. Deming D, et al. Vaccine efficacy in senescent mice challenged with recombinant SARS-CoV bearing 
epidemic and zoonotic spike variants. PLoS Med. 2006;3(12):e525-e525525.

36. DiNapoli JM, et al. Newcastle disease virus, a host range-restricted virus, as a vaccine vector for intranasal immunization against emerging pathogens. Proc Natl Acad Sci USA. 2007;104(23):9788-93.

37. Zhao J, et al. Airway memory CD4+ T cells mediate protective immunity against emerging respiratory coronaviruses. Immunity. 2016;44(6):1379-91.

38. Czub M, Weingartl H, Czub S, He R, Cao J. Evaluation of modified vaccinia virus Ankara based recombinant SARS vaccine in ferrets. Vaccine. 2005;23(17):2273-9.

39. Bisht $\mathrm{H}$, et al. Severe acute respiratory syndrome coronavirus spike protein expressed by attenuated vaccinia virus protectively immunizes mice. Proc Natl Acad Sci USA. 2004;101(17):6641-6.

40. Weingartl $\mathrm{H}$, et al. Immunization with modified vaccinia virus Ankara-based recombinant vaccine against severe acute respiratory syndrome is associated with enhanced hepatitis in ferrets. J Virol. 2004;78(22):12672-6.

41. Chen Z, et al. Recombinant modified vaccinia virus Ankara expressing the spike glycoprotein of severe acute respiratory syndrome coronavirus induces protective neutralizing antibodies primarily targeting the receptor binding region. J Virol. 2005;79(5): 2678-88.

42. Shim B-S, et al. Sublingual immunization with recombinant adenovirus encoding SARS-CoV spike protein induces systemic and mucosal immunity without redirection of the virus to the brain. Virol J. 2012;9(1):215.

43. See $\mathrm{RH}$, et al. Comparative evaluation of two severe acute respiratory syndrome (SARS) vaccine candidates in mice challenged with SARS coronavirus. J Gen Virol. 2006;87(3):641-50.

44. See RH, et al. Severe acute respiratory syndrome vaccine efficacy in ferrets: whole killed virus and adenovirus-vectored vaccines. J Gen Virol. 2008;89(9):2136-46.

45. Yang Z, et al. A DNA vaccine induces SARS coronavirus neutralization and protective immunity in mice. Nature. 2004;428(6982):561-4.

46. Wang S, et al. Identification of two neutralizing regions on the severe acute respiratory syndrome coronavirus spike glycoprotein produced from the mammalian expression system. J Virol. 2005;79(3): 1906-10.
47. Kam YW, et al. Antibodies against trimeric S glycoprotein protect hamsters against SARS-CoV challenge despite their capacity to mediate FcgammaRII-dependent entry into B cells in vitro. Vaccine. 2007;25(4):729-40.

48. Zhou Z, et al. A recombinant baculovirus-expressed $S$ glycoprotein vaccine elicits high titers of SARSassociated coronavirus (SARS-CoV) neutralizing antibodies in mice. Vaccine. 2006;24(17):3624-31.

49. Du L, et al. Receptor-binding domain of SARS-CoV spike protein induces long-term protective immunity in an animal model. Vaccine. 2007;25(15): 2832-8.

50. He Y, et al. Receptor-binding domain of SARS-CoV spike protein induces highly potent neutralizing antibodies: implication for developing subunit vaccine. Biochem Biophys Res Commun. 2004;324(2):773-81.

51. Zakhartchouk $A N$, et al. Immunogenicity of a receptor-binding domain of SARS coronavirus spike protein in mice: implications for a subunit vaccine. Vaccine. 2007;25(1):136-43.

52. He Y, Li J, Heck S, Lustigman S, Jiang S. Antigenic and immunogenic characterization of recombinant baculovirus-expressed severe acute respiratory syndrome coronavirus spike protein: implication for vaccine design. J Virol. 2006;80(12):5757-67.

53. Lokugamage KG, et al. Chimeric coronavirus-like particles carrying severe acute respiratory syndrome coronavirus (SCoV) S protein protect mice against challenge with SCoV. Vaccine. 2008;26(6):797-808.

54. Huang J, Cao Y, Du J, Bu X, Ma R, Wu C. Priming with SARS COV S DNA and boosting with SARS CoV $\mathrm{S}$ epitopes specific for CD4+ and CD8+ $\mathrm{T}$ cells promote cellular immune responses. Vaccine. 2007;25(39-40):6981-91.

55. Kong W, et al. Modulation of the immune response to the severe acute respiratory syndrome spike glycoprotein by gene-based and inactivated virus immunization. J Virol. 2005;79(22):13915-23.

56. Du L, et al. Priming with rAAV encoding RBD of SARS-CoV S protein and boosting with RBD-specific peptides for $\mathrm{T}$ cell epitopes elevated humoral and cellular immune responses against SARS-CoV infection. Vaccine. 2008;26(13):1644-51.

57. Zhao L, et al. Nanoparticle vaccines. Vaccine. 2014;32(3):327-37.

58. Modjarrad K, et al. Safety and immunogenicity of an anti-Middle East respiratory syndrome coronavirus DNA vaccine: a phase 1, open-label, single- 
arm, dose-escalation trial. Lancet Infect Dis. 2019;19(9):1013-22.

59. N. and events University of Oxford. New MERS vaccine clinical trial starts in Saudi Arabia. 2019. [Online]. https://www.ox.ac.uk/news/2019-12-19-new-mersvaccine-clinical-trial-starts-saudi-arabia. Accessed 15 Feb 2020.

60. NIH-ClinicalTrial.gov. Safety, Tolerability and Immunogenicity of Vaccine Candidate MVA-MERSS. 2019. [Online]. https://clinicaltrials.gov/ct2/ show/NCT03615911\#outcomemeasures. Accessed 15 Feb 2020.

61. Schindewolf C, Menachery DV. Middle East respiratory syndrome vaccine candidates: cautious optimism. Viruses. 2019;11(1):74.

62. Xia S, et al. Middle East respiratory syndrome coronavirus (MERS-CoV) entry inhibitors targeting spike protein. Virus Res. 2014;194:200-10.

63. Almazan F, et al. Engineering a replication-competent, propagation-defective Middle East respiratory syndrome coronavirus as a vaccine candidate. MBio. 2013;4(5):e00650-e713.

64. Wirblich C, et al. One-health: a safe, efficient, dualuse vaccine for humans and animals against Middle East respiratory syndrome coronavirus and rabies virus. J Virol. 2017;91(2):e02040-e2116.

65. Deng Y, et al. Enhanced protection in mice induced by immunization with inactivated whole viruses compare to spike protein of middle east respiratory syndrome coronavirus. Emerg Microbes Infect. 2018;7(1):60.

66. Agrawal AS, et al. Immunization with inactivated Middle East Respiratory Syndrome coronavirus vaccine leads to lung immunopathology on challenge with live virus. Hum Vaccin Immunother. 2016;12(9):2351-6.

67. Kim E, et al. Immunogenicity of an adenoviralbased Middle East Respiratory syndrome coronavirus vaccine in BALB/c mice. Vaccine. 2014;32(45):5975-82.

68. Munster VJ, et al. Protective efficacy of a novel simian adenovirus vaccine against lethal MERS-CoV challenge in a transgenic human DPP4 mouse model. npj Vaccines. 2017;2(1):28.

69. Volz A, et al. Protective efficacy of recombinant modified vaccinia virus Ankara delivering Middle East respiratory syndrome coronavirus spike glycoprotein. J Virol. 2015;89(16):8651-6.

70. Malczyk AH, et al. A highly immunogenic and protective Middle East respiratory syndrome coronavirus vaccine based on a recombinant measles virus vaccine platform. J Virol. 2015;89(22): 11654-67.

71. Haagmans BL, et al. An orthopoxvirus-based vaccine reduces virus excretion after MERS-CoV infection in dromedary camels. Science. 2015;351(6268): 77-81.

72. Guo X, et al. Systemic and mucosal immunity in mice elicited by a single immunization with human adenovirus type 5 or 41 vector-based vaccines carrying the spike protein of Middle East respiratory syndrome coronavirus. Immunology. 2015;145(4): 476-84.

73. Kato $\mathrm{H}$, et al. Development of a recombinant replication-deficient rabies virus-based bivalentvaccine against MERS-CoV and rabies virus and its humoral immunogenicity in mice. PLoS One. 2019;14(10):e0223684.

74. Alharbi NK, et al. ChAdOx1 and MVA based vaccine candidates against MERS-CoV elicit neutralising antibodies and cellular immune responses in mice. Vaccine. 2017;35(30):3780-8.

75. Alharbi NK, et al. Humoral immunogenicity and efficacy of a single dose of ChAdOx1 MERS vaccine candidate in dromedary camels. Sci Rep. 2019;9(1): 16292.

76. Hashem AM, et al. A highly immunogenic, protective, and safe adenovirus-based vaccine expressing middle east respiratory syndrome coronavirus S1CD40L fusion protein in a transgenic human dipeptidyl peptidase 4 mouse model. J Infect Dis. 2019;220(10):1558-677.

77. Lan J, et al. Recombinant receptor binding domain protein induces partial protective immunity in rhesus macaques against Middle East respiratory syndrome coronavirus challenge. EBioMedicine. 2015;2(10):1438-46.

78. Wang L, et al. Evaluation of candidate vaccine approaches for MERS-CoV. Nat Commun. 2015;6: 7712.

79. Tai W, et al. A recombinant receptor-binding domain of MERS-CoV in trimeric form protects human dipeptidyl peptidase 4 (hDPP4) transgenic mice from MERS-CoV infection. Virology. 2016;499:375-82.

80. Wang Y, et al. Receptor-binding domain of MERS$\mathrm{CoV}$ with optimal immunogen dosage and immunization interval protects human transgenic mice from MERS-CoV infection. Hum Vaccin Immunother. 2017;13(7):1615-24. 
81. Adney RD, et al. Efficacy of an adjuvanted Middle East respiratory syndrome coronavirus spike protein vaccine in dromedary camels and alpacas. Viruses. 2019;11(3):212.

82. Zhang $\mathrm{Y}$, et al. Effects of the fusion design and immunization route on the immunogenicity of Ag85A-Mtb32 in adenoviral vectored tuberculosis vaccine. Hum Vaccin Immunother. 2015;11(7): 1803-13.

83. $\mathrm{Ma} \mathrm{C}$, et al. Intranasal vaccination with recombinant receptor-binding domain of MERS-CoV spike protein induces much stronger local mucosal immune responses than subcutaneous immunization: Implication for designing novel mucosal MERS vaccines. Vaccine. 2014;32(18):2100-8.

84. Tang J, et al. Optimization of antigen dose for a receptor-binding domain-based subunit vaccine against MERS coronavirus. Hum Vaccin Immunother. 2015;11(5):1244-50.

85. Nyon MP, et al. Engineering a stable CHO cell line for the expression of a MERS-coronavirus vaccine antigen. Vaccine. 2018;36(14):1853-62.

86. Zhang $\mathrm{N}$, et al. Identification of an ideal adjuvant for receptor-binding domain-based subunit vaccines against Middle East respiratory syndrome coronavirus. Cell Mol Immunol. 2016;13(2):180-90.

87. Lan J, et al. Tailoring subunit vaccine immunity with adjuvant combinations and delivery routes using the Middle East respiratory coronavirus (MERS-CoV) receptor-binding domain as an antigen. PLoS One. 2014;9(11):e112602.

88. Coleman CM, et al. MERS-CoV spike nanoparticles protect mice from MERS-CoV infection. Vaccine. 2017;35(12):1586-9.

89. Coleman CM, et al. Purified coronavirus spike protein nanoparticles induce coronavirus neutralizing antibodies in mice. Vaccine. 2014;32(26):3169-74.

90. EurekAlert! News Release. MERS-CoV vaccine is safe and induces strong immunity in Army-led first-inhuman trial. 2019. [Online]. https://www. eurekalert.org/pub_releases/2019-07/wrai-mvi0723 19.php. Accessed 15 Feb 2020.

91. Muthumani $\mathrm{K}$, et al. A synthetic consensus antispike protein DNA vaccine induces protective immunity against Middle East respiratory syndrome coronavirus in nonhuman primates. Sci Transl Med. 2015;7(301):301ra132.

92. Chi $\mathrm{H}$, et al. DNA vaccine encoding Middle East respiratory syndrome coronavirus $\mathrm{S} 1$ protein induces protective immune responses in mice. Vaccine. 2017;35(16):2069-75.
93. WHO. DRAFT landscape of COVID-19 candidate vaccines-20 March 2020. 2020. [Online]. https://www. who.int/blueprint/priority-diseases/key-action/novelcoronavirus-landscape-ncov.pdf?ua=1. Accessed 15Mar 2020.

94. pharmaceutical-technology.com. First US clinical trial of Covid-19 vaccine candidate begins. 2020 [Online]. https://www.pharmaceutical-technology. com/news/first-us-covid-19-vaccine-trial-moderna/. Accessed 10 Apr 2020.

95. Sutton TC, Subbarao K. Development of animal models against emerging coronaviruses: From SARS to MERS coronavirus. Virology. 2015;479-480: 247-58.

96. Zhao J, et al. Rapid generation of a mouse model for Middle East respiratory syndrome. Proc Natl Acad Sci USA. 2014;111(13):4970-5.

97. Munster VJ, de Wit E, Feldmann H. Pneumonia from human coronavirus in a macaque model. N Engl J Med. 2013;368(16):1560-2.

98. de Wit E, Rasmussen AL, Falzarano D, Bushmaker T, Feldmann F, Brining DL. Middle East respiratory syndrome coronavirus (MERS-CoV) causes transient lower respiratory tract infection in rhesus macaques. Proc Natl Acad Sci USA. 2013;110:16598-603.

99. Falzarano D, et al. Infection with MERS-CoV causes lethal pneumonia in the common marmoset. PLoS Pathog. 2014;10(8):e1004250.

100. Chan JF-W, et al. Treatment with lopinavir/ritonavir or interferon- $\beta 1 \mathrm{~b}$ improves outcome of MERS$\mathrm{CoV}$ infection in a nonhuman primate model of common marmoset. J Infect Dis. 2015;212(12): 1904-13.

101. McAuliffe J, et al. Replication of SARS coronavirus administered into the respiratory tract of African Green, rhesus and cynomolgus monkeys. Virology. 2004;330(1):8-15.

102. Lawler JV, et al. Cynomolgus macaque as an animal model for severe acute respiratory syndrome. PLoS Med. 2006;3(5):e149-e149149.

103. Jiang S, He Y, Liu S. SARS vaccine development. Emerg Infect Dis J. 2005;11(7):1016.

104. Du L, Tai W, Zhou Y, Jiang S. Vaccines for the prevention against the threat of MERS-CoV. Expert Rev Vaccines. 2016;15(9):1123-34.

105. Payne S. Chapter 6-immunity and resistance to viruses. In: Payne SBT-V, editor. Viruses From Understanding to Investigation. Academic Press; 2017. p. 61-71. 
106. Haagmans BL, et al. An orthopoxvirus-based vaccine reduces virus excretion after MERS-CoV infection in dromedary camels. Science. 2016;351(6268): 77-81.

107. Pascal KE, et al. Pre- and postexposure efficacy of fully human antibodies against Spike protein in a novel humanized mouse model of MERS-CoV infection. Proc Natl Acad Sci USA. 2015;112(28): 8738-43.

108. Liu WJ, et al. Protective T cell responses featured by concordant recognition of Middle East respiratory syndrome coronavirus-derived CD8+ T cell epitopes and host MHC. J Immunol. 2017;198(2): 873-82.

109. Zhao J, Zhao J, Perlman S. T cell responses are required for protection from clinical disease and for virus clearance in severe acute respiratory syndrome coronavirus-infected mice. J Virol. 2010;84(18): 9318-25.

110. Li T, et al. Long-term persistence of robust antibody and cytotoxic $\mathrm{T}$ cell responses in recovered patients infected with SARS coronavirus. PLoS One. 2006;1(1):e24-e2424.

111. Park WB, Perera RAPM, Choe PG, Lau EHY, Choi SJ, Chun JY. Kinetics of serologic responses to MERS coronavirus infection in humans, South Korea. Emerg Infect Dis. 2015;21:2186-9.

112. Min C-K, et al. Comparative and kinetic analysis of viral shedding and immunological responses in MERS patients representing a broad spectrum of disease severity. Sci Rep. 2016;6(1):25359.

113. $\mathrm{Gu} \mathrm{J}$, et al. Multiple organ infection and the pathogenesis of SARS. J Exp Med. 2005;202(3): 415-24.

114. Zhao J, et al. Recovery from the Middle East respiratory syndrome is associated with antibody and $\mathrm{T}$ cell responses. Sci Immunol. 2017;2(14):eaan5393.

115. Tang F, et al. Lack of peripheral memory B cell responses in recovered patients with severe acute respiratory syndrome: a 6-year follow-up study. J Immunol. 2011;186(12):7264-8.

116. Liu W, et al. Two-year prospective study of the humoral immune response of patients with severe acute respiratory syndrome. J Infect Dis. 2006;193(6):792-5.

117. Payne DC, et al. Persistence of antibodies against Middle East respiratory syndrome coronavirus. Emerg Infect Dis. 2016;22(10):1824-6.

118. Bradburne AF, Somerset BA. Coronative antibody tires in sera of healthy adults and experimentally infected volunteers. J Hyg (Lond). 1972;70(2): 235-44.

119. Callow KA, Parry HF, Sergeant M, Tyrrell DA. The time course of the immune response to experimental coronavirus infection of man. Epidemiol Infect. 1990;105(2):435-46.

120. Dimmock K, Easton NJ, Leppard AJ. Introduction to modern virology. In: Malden MA, editor. Introduction to modern virology. New York: Blackwell Pub; 2007. p. 65.

121. Vennema $H$, et al. Early death after feline infectious peritonitis virus challenge due to recombinant vaccinia virus immunization. J Virol. 1990;64(3): 1407-9.

122. Houser KV, et al. Enhanced inflammation in New Zealand white rabbits when MERS-CoV reinfection occurs in the absence of neutralizing antibody. PLoS Pathog. 2017;13(8):e1006565-e10065651006565.

123. Greenough TC, et al. Development and characterization of a severe acute respiratory syndrome-associated coronavirus-neutralizing human monoclonal antibody that provides effective immunoprophylaxis in mice. $\mathrm{J}$ Infect Dis. 2005;191(4):507-14.

124. Subbarao K, et al. Prior infection and passive transfer of neutralizing antibody prevent replication of severe acute respiratory syndrome coronavirus in the respiratory tract of mice. J Virol. 2004;78(7):3572-7.

125. Hearnden C, Lavelle EC. Chapter 21-adjuvant strategies for vaccines: the use of adjuvants within the cancer vaccine setting. In: Prendergast GC, Jaffee E, editors. EMBT-CI. San Diego: Academic Press; 2013. p. 333-349.

126. Honda-Okubo Y, Barnard D, Ong CH, Peng B-H, Tseng C-TK, Petrovsky N. Severe acute respiratory syndrome-associated coronavirus vaccines formulated with delta inulin adjuvants provide enhanced protection while ameliorating lung eosinophilic immunopathology. J Virol. 2015;89(6):2995-3007.

127. Blaauboer SM, Mansouri S, Tucker HR, Wang HL, Gabrielle VD, Jin L. The mucosal adjuvant cyclic diGMP enhances antigen uptake and selectively activates pinocytosis-efficient cells in vivo. Elife. 2015;4:e6670.

128. N.-N. Releases. NIH clinical trial of investigational vaccine for COVID-19 begins. 2020. [Online]. https://www.nih.gov/news-events/news-releases/ nih-clinical-trial-investigational-vaccine-covid-19begins. Accessed 10 Apr 2020. 
129. Hodgson J. The pandemic pipeline. Nat Biotechnol. 2020. Online ahead of print.

130. Agnihothram S, et al. Evaluation of serologic and antigenic relationships between Middle Eastern respiratory syndrome coronavirus and other coronaviruses to develop vaccine platforms for the rapid response to emerging coronaviruses. J Infect Dis. 2013;209(7):995-1006.

131. Peng $\mathrm{H}$, et al. Long-lived memory $\mathrm{T}$ lymphocyte responses against SARS coronavirus nucleocapsid protein in SARS-recovered patients. Virology. 2006;351(2):466-75. 